Z. Klin. Chem. Klin. Biochem.

13. Jg. 1975 , S. $387-393$

\title{
A Systematic Investigation on the Hemalog
}

\author{
By W. P. F. Rutten, R. J. H. Scholtis, N. A. Schmidt and R. J. M. van Oers
}

Stichting Medische Laboratoria, Breda, The Netherlands

(Eingegangen am 11. Oktober 1974/1. April 1975)

The Hemalog system is an automated hematological instrument. From one sample this instrument determines the value for platelets $(\mathrm{PBC})$, white blood cells $(\mathrm{WBC})$, red blood cells $(\mathrm{RBC})$, hemoglobin $(\mathrm{Hb})$ and the hematocrit simultaneously.

Moreover the system calculates the derived values: the mean cell volume (MCV), mean cell hemoglobin (MCH) and the mean cell hemoglobin concentration (MCHC). The values were investigated for cross sample contamination, coincidence, reproducibility, and compared with other methods. From this comparative study we can conclude that the Hemalog is a suitable and reliable instrument for hematological determination.

\section{Systematische Untersuchung des Hemalog}

Das Hemalog-System ist ein automatisiertes hämatologisches Instrument. Aus einer Probe bestimmt das Gerät simultan Thrombo-, Leuko- und Erythrocytenzahl sowie Hämoglobin und Hämatokrit. Außerdem berechnet das System die abgeleiteten Größen mittleres Zellvolumen, mittleren Zellhämoglobingehalt und mittlere Zellhämoglobinkonzentration. Die Werte werden hinsichtlich Verschleppung, Ubereinstimmung und Reproduzierbarkeit untersucht und mit anderen Methoden verglichen.

Aus dieser vergleichenden Untersuchung können wir schließen, daß der Hemalog ein geeignetes und zuverlässiges Instrument für hämatologische Bestimmungen ist.

\section{Introduction}

The increasing number of hematological determinations favours the move towards a high degree of automation in this field. Various firms (Coulter electronics (Hialeah, Florida), Fisher Scientifics Co. (Pittsburg)) produce commercial apparatus, which, from one specimen of whole blood, perform a number of hematological determinations at the same time. The Technicon Co. (Tarrytown, New York) produces a continuous flow system, the Hemalog. This apparatus determines 8 blood parameters with $1.4 \mathrm{ml}$ of EDTA anticoagulated blood. These ${ }^{1}$ ) are: the number of platelets (PBC),

\footnotetext{
1) Abbreviations:

$\mathrm{PBC}=$ Platelet Blood Corpuscles

WBC = White Blood Corpuscles

RBC = Red Blood Corpuscles

PCV = Packed Cell Volume, Hematocrit

MCV = Mean Cell Volume

$\mathrm{MCH}=$ Mean Cell Hemoglobin

MCHC = Mean Cell Hemoglobin Concentration
}

white blood cells (WBC), red blood cells (RBC), hemoglobin (Hb), hematocrit (PCV), and the derived values: the $\operatorname{MCV}\left(=\frac{\mathrm{PCV}}{\mathrm{RBC}}\right)$, the $\mathrm{MCH}\left(=\frac{\mathrm{Hb}}{\mathrm{RBC}}\right)$ and the MCHC $\left(=\frac{\mathrm{Hb}}{\mathrm{PCV}}\right)$.

All results are presented in digital form with a speed of 60 samples per hour. The counting of cells is performed with the aid of optical systems: the hemoglobin is measured spectrophotometrically with the cyanide-hemiglobin method, the hematocrit is determined in a continuous centrifuging process.

Cross sample contamination or coincidence has been checked, and reproducibility within a series and the reproducibility from series to series have been determined. In addition the comparability with other current methods has been checked. 


\section{Materials and Methods}

Sample

The blood from the patient was drawn into Venoject tubes (Jintan Terumo Co LTD, Tokyo Japan) ( $3 \mathrm{ml}$ ) containing dipotassium ethylenediamine tetraacetate (EDTA) as an anticoagulant. All determinations were completed within three hours after the sample was drawn.

Hemalog

Platelets

About $0.2 \mathrm{ml}$ of EDTA anticoagulated blood is diluted 1500 times with $2 \mathrm{~mol} / 1$ urea. The red blood cells are lysed by this reagent; the white blood cells are counted with the platelets.

To obtain an absolute value the leucocytes should be subtracted from the platelets. In normal blood the number of white blood cells with regard to the number of platelets is not significant.

\section{White blood cells}

About $0.2 \mathrm{ml}$ of EDTA anticoagulated blood is diluted 100 times with a solution which contains $9 \mathrm{~g} \mathrm{NaCl}$ and $5 \mathrm{ml}$ acetic acid per liter of distilled water. This solution lyses the platelets and the red blood cells. The white blood cells are counted with the aid of an optical system.

\section{Hematocrit}

From $0.5 \mathrm{ml}$ of blood anticoagulated with EDTA a small portion is taken and centrifuged at 23000 r.p.m. for $50 \mathrm{~s}$. With an optical system the boundary layer between the cells and the solution is determined.

\section{Red blood cells}

About $0.04 \mathrm{ml}$ of blood anticoagulated with EDTA is diluted about 14,000 times with a buffered salt solution $(11.75 \mathrm{~g}$ of sodium diethyl barbiturate; $14.67 \mathrm{~g}$ of $\mathrm{NaCl} ; 0.5 \mathrm{ml}$ of the detergent Brij 35 per 2 liters of distilled water adjusted to $\mathrm{pH}$ 7.1 with $1 \mathrm{~mol} / 1 \mathrm{HCl}$ ).

The red blood cells are counted with the aid of the optical system.

\section{Hemoglobin}

Blood anticoagulated with EDTA is diluted with buffered salt solution (11.75 $\mathrm{g}$ of sodium diethyl barbiturate; $14.67 \mathrm{~g}$ of $\mathrm{NaCl}$; $0.5 \mathrm{ml}$ of the detergent BRIJ 35 per 2 liters adjusted to $\mathrm{pH} 7.1$ with $1 \mathrm{~mol} / 1 \mathrm{HCl}$.) This solution is once more diluted with Hb-reagent $\left(0.60 \mathrm{~g} \mathrm{KCN}^{2} 4.8 \mathrm{~g} \mathrm{NaHCO}_{3} ; 4.8 \mathrm{~g} \mathrm{~K}_{3} \mathrm{Fe}(\mathrm{CN})_{6}\right.$ per liter of distilled water). This solution is led along a lamp to ensure the conversion of resistent hemoglobin into cyanide-hemiglobin. The absorption is measured in a dual beam spectrophotometer at $550 \mathrm{~nm}$.

\section{$M C V, M C H, M C H C$}

The Hemalog calculates these values from their ground parameters.

\section{Calibration}

The Hemalog requires calibration for each batch. The parameters which require this calibration are platelets, white blood cells, red blood cells and hemoglobin. The manufacturer provides two different samples. One sample is used for the calibration of platelets and the other one for the calibration of white blood cells, red blood cells and hemoglobin.

\section{Working method}

The Hemalog is used as prescribed by the manufacturer. No changes have been introduced into the system so far.

Other current methods

\section{Thrombocytes}

according to Fcissly (1)

White blood cells

$0.02 \mathrm{ml}$ of blood anticoagulated with EDTA is diluted 500 times with isotonic salt solution $(9 \mathrm{~g} / \mathrm{l} \mathrm{NaCl})$. To this solution $0.1 \mathrm{ml}$ of "lysing and hemoglobin reagent" is added. Within 5 minutes the leucocytes are counted with the aid of the Coulter Model Fn. The determination is executed in duplicate.

\section{Red Slood cells}

$0.02 \mathrm{ml}$ of blood anticoagulated with EDTA is diluted 50,000 times with isotonic salt solution. This solution is counted with the Coulter Counter Model Fn(Coulter Diagnostics, Miami Springs, Florida). The determination is executed in duplicate. The number of red blood cells is corrected with the aid of a coincidence table.

\section{Hemoglobin}

according to Van Kampen \& Zijlstra (2)

\section{Hematocrit}

We have used two methods:

a) The hematocrit is determined with the aid of the Martin Christ (Osterode/Harz Western Germany) microhematocrite centrifuge with $75 \mathrm{~mm}$ capillary tubes.

b) The hematocrit is given as the derived value by the hematocrit computer of the Coulter Counter Model Fn.

\section{$M C V$}

When counting the red blood cells, the pulse heights are measured with the Coulter Fn. The MCV-computer determines the MCV from the average pulse-heights.

\section{Results}

\section{Calibration}

The calibration of platelets caused a good many problems. When setting the value as indicated by the manufacturer the values of the patient-samples compared with the values determined with the Feissly method appeared to be $1 / 3$ too high. This would mean that the number given in the reference sample was too high. This sample was counted several times in the counting chamber. From this it appeared that the number given by Technicon for the reference sample was correct.

A second possibility was that the threshold value for the calibration sample, which consists of platelets from turkeys, was different from that of men. When the value for the threshold for the calibration sample was checked, it appeared to be about the same as it was for the patient sample. As a third possibility, by which too low a number of platelets could be measured, it was suggested that during calibration an aggregation could occur and cause a number of platelets to be counted at the same time. Microscopically, however, there was no aggregation to be seen. The reason for this low value is still unknown.

From experience, it appears that we can work satisfactorily with a factor. Out of a hundred comparative determinations with the hand method a factor of 0.71 was determined. This factor multiplied by the value indicated by the manufacturer is taken as the calibration value of platelets. We had no problems with the calibration of white blood cells, red blood cells, hemoglobin, and the hematocrit. 


\section{Contamination}

The contamination of the Hemalog has been checked according to the method of Thiers et al. (3). No contamination could be determined for white blood cells, red blood cells, hemoglobin and hematocrit. A slight contamination was seen for the platelets. The percentage of interaction for the platelets is $1 \%$.

This means that the contamination is less than contamination for red and white cells as measured by Brittin et al (4) for the Coulter Counter Model S. The contamination for the red blood cells, white blood cells, and hemoglobin for the SMA-7A given by Nicoll \& Smith (5) is greater than the contamination of the Hemalog.

\section{Reproducibility within the series}

With six different samples the reproducibility within a series was checked. Each sample was taken a number of times per batch with a fixed interval.

The results obtained are shown in table 1.

In the last columns the coefficients of variation of the six samples are showed besides the coefficients of variation indicated by the manufacturer. From this table it appears that most measured values correspond well with the values indicated by the manufacturer. For the white blood cells sample 1 and 3 are significantly higher. The coefficient of variation for the Coulter Counter model S given by Britten et al (4) was a bit smaller than we had measured on the Hemalog for the white blood cells and the hematocrit and about the same for red blood cells and hemoglobin.

\section{Reproducibility from series to series}

For the determination of the reproducibility from series to series a commercial test sample was used. Though different samples were always used, these samples can be divided into two groups. One group consisted of samples with abnormal values (white blood cells high, red blood cells, hemoglobin and hematocrite low) and the other one consisted of a sample with all values in the normal range. These samples do not contain platelets.

The results for six samples are shown in table 2 .

The last columns show the coefficient of variation as measured for the six samples, beside the coefficient of variation as indicated by the manufacturer. The manufacturer gives this coefficient for a limited area. For the white blood cells it is from 5 to $9 \cdot 10^{9}$ per liter; for the red blood cells from 4.0 to $6.0 \cdot 10^{12}$ per liter; for the hemoglobin from 7.3 to $11.0 \mathrm{mmol} / \mathrm{l} \mathrm{Fe}$ and for the hematocrit it is from 38 to $54 \%$. A significant difference in variation coefficients between normal and abnormal samples could not be demonstrated. It should be noted, however, that for samples with normal values
- they fall within the area as stated by the manufacturer at the determination of coefficients of variation - the coefficients of variation for red blood cells, hemoglobin and hematocrit are greater than indicated by the manufacturer.

Nicoll \& Smith (5) found a much greater coefficient of variation on the SMA-7A for the white blood cells; the values for the coefficient of variation for the red blood cell hemoglobin were about the same. From the values given by Britten et al (4) for the Coulter Counter Model $S$ we could derive that the coefficient of variation for the white blood cells is greater and the coefficient of variation for red blood cells, hemoglobin and hematocrite are smaller than we determine for the Hemalog.

\section{Comparability with other current methods}

All determinations of the hemalog have been compared with other current methods. For all determinations at least 70 comparative determinations have been executed. The results are shown in the figures 1 to 7 . For all determinations the correlation coefficient has been calculated. These values are shown in table 3 . The values for the platelets on the Hemalog are the values calibrated on the reference sample multiplied by 0.71 as indicated above.

For the platelets it can be derived from these data that the values correspond reasonably with each other. Especially when taking into account that the handmethod has a great coefficient of variation $( \pm 10 \%)$. In figure 1 it could be seen, however, that there are still a few determinations with remarkable differences.

Several authors $(6,7,8)$ indicate that too low a number of platelets is due to cold agglutinines of platelets. These agglutinines would cause the platelets to clot and a lower number of platelets in the optical and electronical system would therefore be counted. Recently, however, in two patients we found a platelet number which was much higher than determined with the method of Feissly. Measurements of platelets of a patient with biliary cirrhosis were performed for two months both on the hemalog and in the counting chamber. The results are given in figure 8 .

On day 41 we found on the hemalog a platelets number of 352 , with the manual procedure we found 40 .

This falsely high number of platelets was caused by the fact that the red blood cells only lyse partially in $2 \mathrm{~mol} / \mathrm{l}$ urea and therefore were counted along with the platelets.

Unter the microscope we could see this clearly. Because this patient had an abnormally high value of reticulocytes we thought for a moment that possibly these cells were more resistant than normocytes, but we cannot find any discrepancy in other patients with high numbers of reticulocytes. 


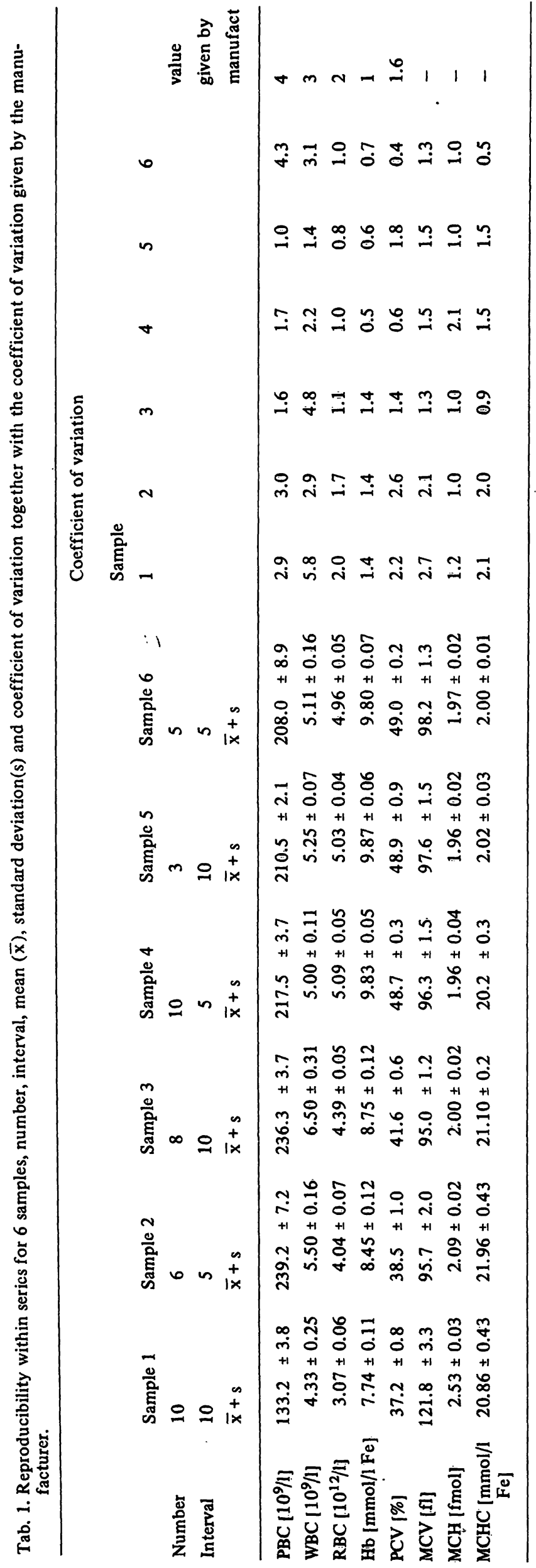

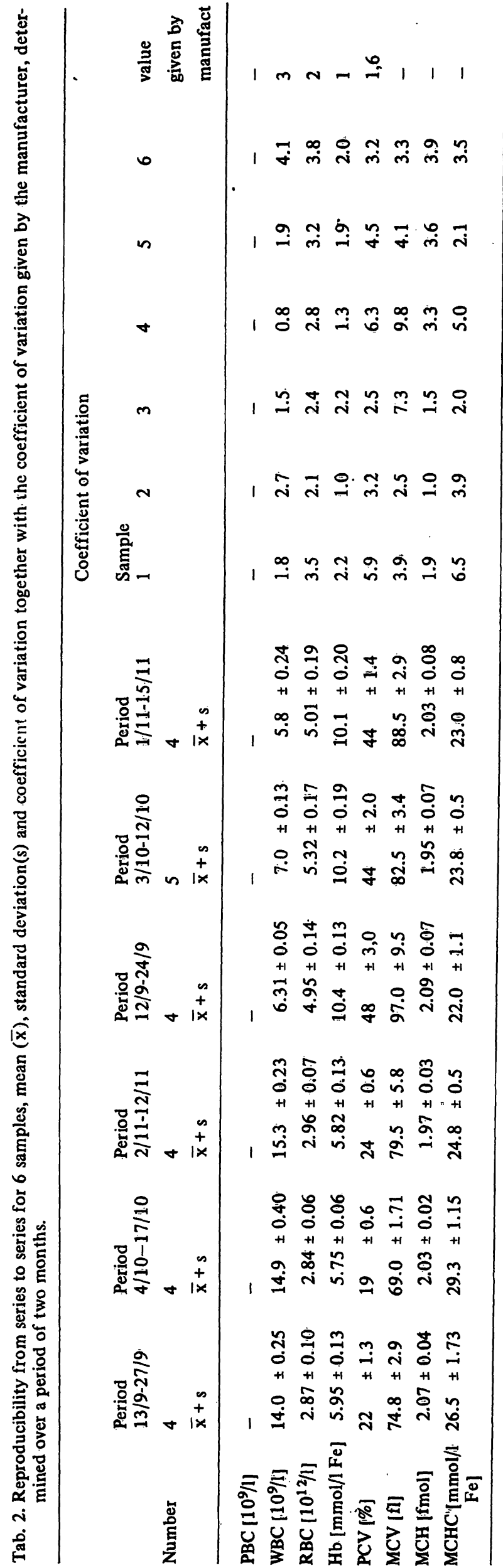


Tab. 3. Correlation coefficients of determinations on the Hemalog and the routine clinical laboratory methods belonging to figure 1 to 7.

\begin{tabular}{llllr}
\hline & Method 1 & Method 2 & Corr. coeff. & Number \\
\hline Platelets (PBC) & Hemalog & Feissly & 0.963 & 74 \\
Whitc blood cells (WBC) & Hemalog & Coulter Fn & 0.987 & 116 \\
Red blood cells (RBC) & Hemalog & Coulter Fn & 0.973 & 119 \\
Hemoglobin (Hb) & Hemalog & Van Kampen \& Zijlstre & 0.987 & 71 \\
Hematocrit (PCV) & Hemalog & Coulter Fn & 0.967 & 106 \\
Hematocrit (PCV) & Hemalog & Centrifuge & 0.954 & 116 \\
Mean cell volume (MCV) & Hemalog & Coulter Fn & 0.731 & 119 \\
\hline
\end{tabular}

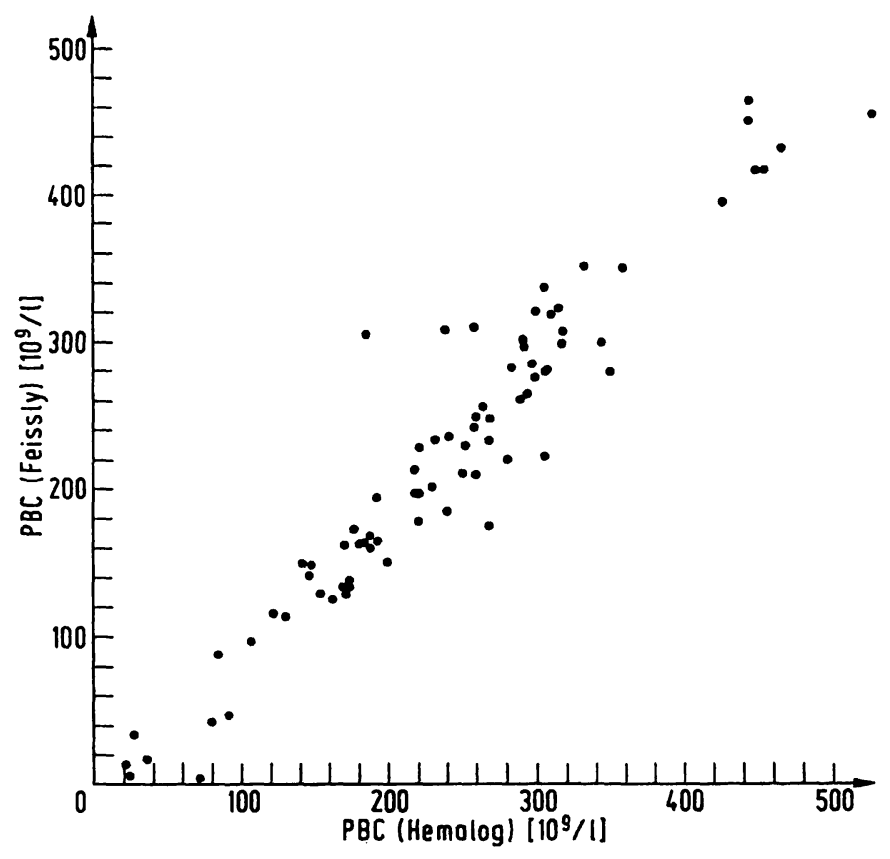

Fig. 1. Platelet values from the Hemalog versus the platelet values determined with the method of Feissly (1). The platelet values of the Hemalog are not corrected for white blood cells.

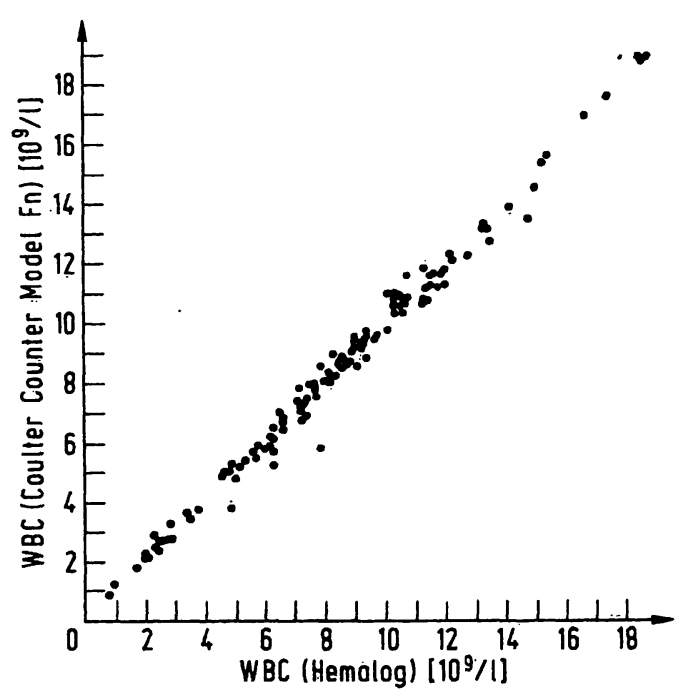

Fig. 2. Leucocyte values of the Hemalog versus the leucocyte values of the Coulter Counter Model Fn.

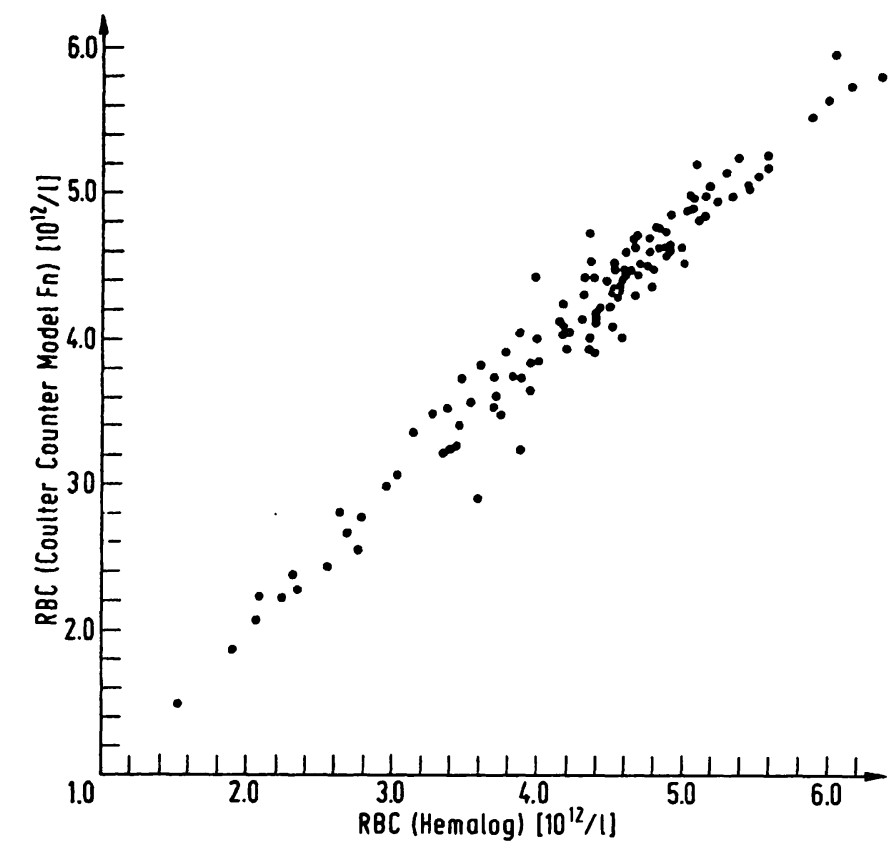

Fig. 3. Erythrocyte values of the Hemalog versus the crytlurocyte values of the Coulter Counter Model Fn.

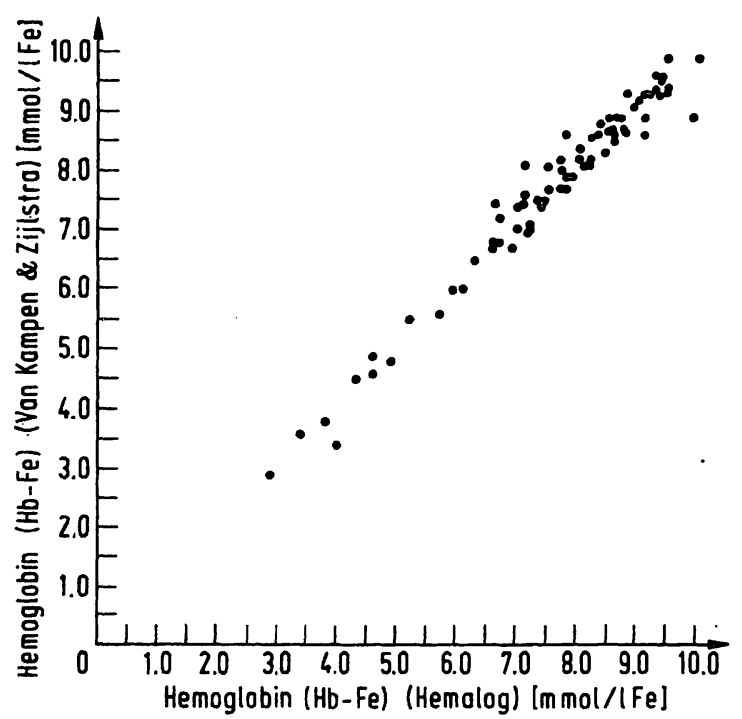

Fig. 4. Hemoglobin values of the Hemalog versus the hemoglobin values, determined after Van Kampen \& Zijlstra (2). 


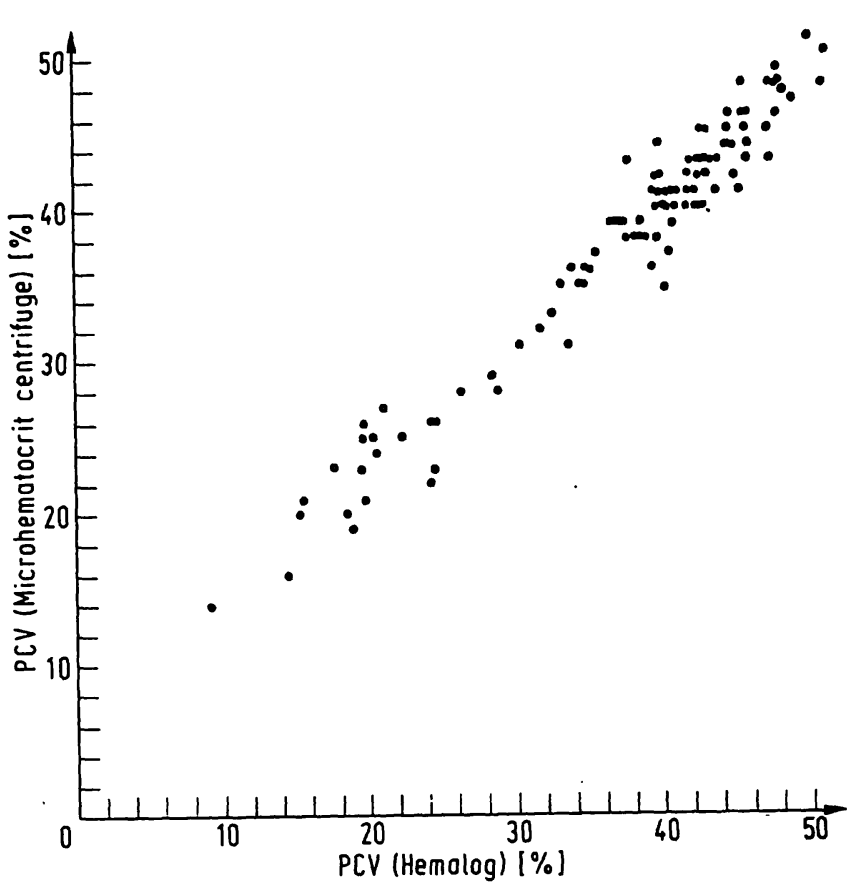

Fig. 5. Hematocrit values of the Hemalog versus the hematocrit determined with the Martin Christ microhematocrit centrifuge.

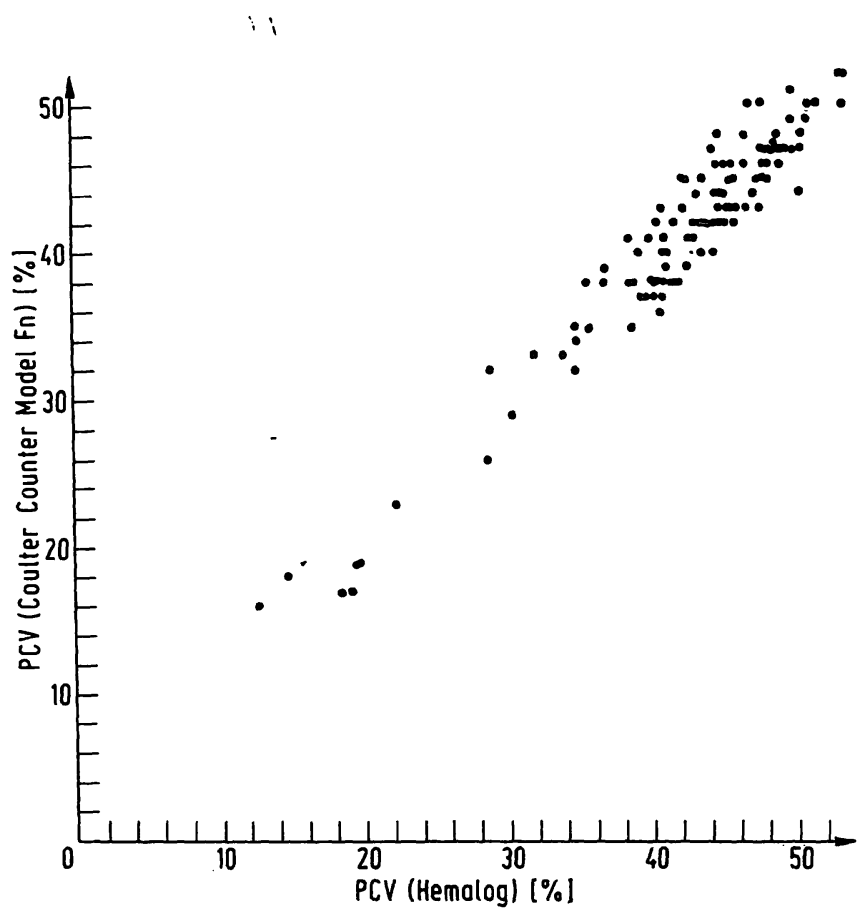

Fig. 6. Hematocrit values of the Hemalog versus the hematocrit determined with the Coulter Counter Model Fn.

The number of platelets of the second patient measured on the Hemalog was 916 , the number determined with the method of Feissly (1) was 319. The reason also was that the red blood cells lyse partially in $2 \mathrm{~mol} / \mathrm{i}$ urea. The values for the leucocytes (figure 2) corresponds with the values measured on the Coulter Fn. This also applies, in a lesser extent, to the red blood cells. Comparison of the hemoglobin value of the Hemalog with

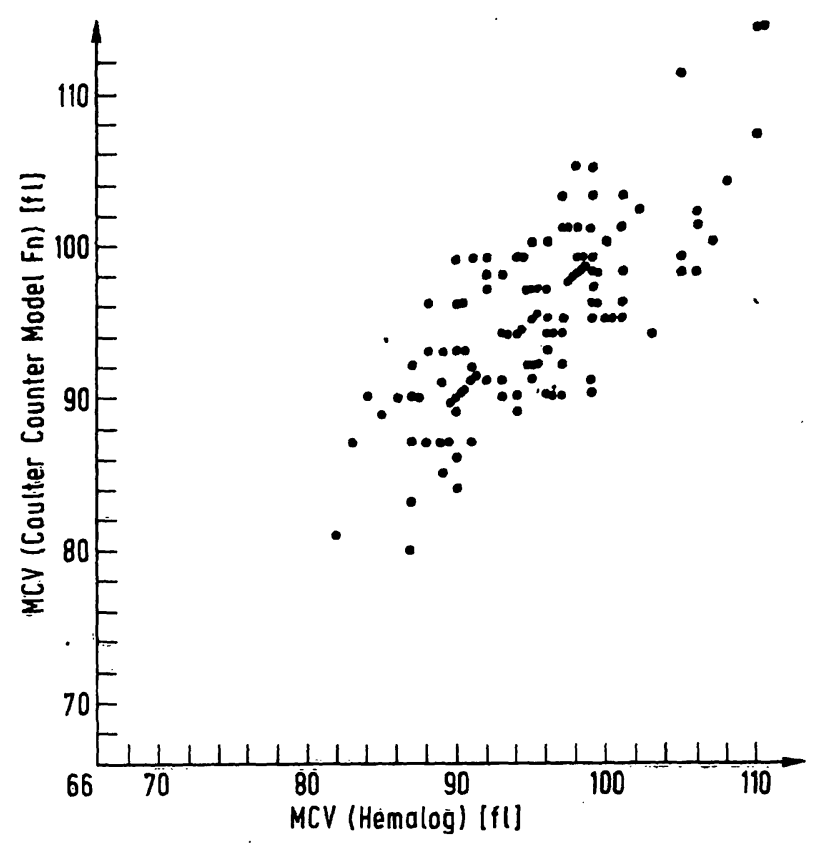

Fig. 7. MCV values of the Hemalog versus the MCV values determined with Coulter Counter Model Fn.

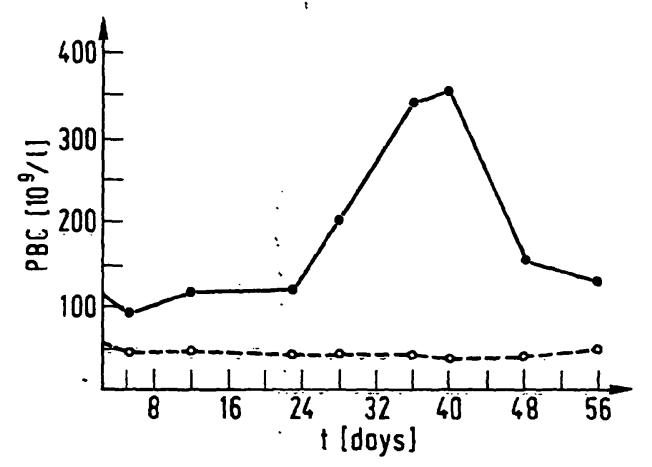

Fig. 8. Platelet values of a patient with biliary cirrhosis determined during two months on the Hemalog $(-)$ and with the method of Feissly (-- ).

the hemoglobin determined with the method of Van Kampen \& Zijlstra (2) shows a good correlation.

The hematocrit of the Hemalog has been compared with the hematocrit determined on the hematocrit centrifuge and with the hematocrit determined on the hematocrit computer of the Coulter Fn. For patients with an extremely high number of white blood cells, the Hemalog gives a wrong value for hematocrit.

Because the Hemalog reads the boundary layer between cells and liquid, it does not see the cone of white blood cells which lies on the red cells, resulting in a falsely high value for the hematocrit. For a patient with a white blood cell count of $120 \times 10^{9} / 1$ the Hemalog measures a hematocrit of $36.9 \%$ whereas the value measured with the centrifuge is $30 \%$. As the Hemalog calculates the MCV and the MCHC from the hematocrit 
it follows from this that these'values are also incorrect. The MCV is much higher (value fo the Hemalog 111, true value 91) and the MCHC is lower (value of the Hemalog 17.6, true value 21.0). The values for the hematocrit measured on the Coulter Counter Model Fn compared with values of the Hemalog, correspond reasonably.

Also the MCV values of the Coulter Counter Model Fn and the Hemalog have been compared. The MCV value of the Coulter Counter Model Fn is a directly measured value. The MCV of the Hemalog is calculated from the hematocrit and the red blood cells. The correlation coefficient of these two determinations is low.

Because of this great difference we do not use the MCV from the Coulter Counter Model Fn, but we calculate the MCV from the hematocrit determined with the micro-hematocrit centrifuge and the red blood cells. This MCV corresponds well with the MCV of the Hema$\log$.

Brittin et al (4) have compared the Coulter Counter Model S with routine clinical laboratory methods. The values which they have found for white blood cells, red blood cells, hemoglobin and hematocrit are about the same as we found in this study.

\section{References}

1. Feissly, R. \& Ludin, H. (1948), Verh. Schweiz Naturf. Ges. $128,179$.

2. Van Kampen, E. J. \& Zijlstra, W. G. (1968), Clin. Chim. Acta 6, 538-544.

3. Thiers, R. E., Cole, R. R. \& Kirsch, W. J. (1967), Clin. Chem. $13,451-467$.

4. Brittin, G. M., Brecher, G. M. \& Johnson, C. (1969), Amer. J. Clin. Path. 52, 679-689.

\section{Conclusion}

From a relatively small quantity of sample the Hemalog supplies a great number of values within a short time. The Technicon Idee system has been fitted into our laboratory computer system so that the results can be obtained quickly and without transcription. For this reason identification mistakes are almost excluded. The Hemalog is the only automated system giving the number of platelets. This determination, as regards the calibration, has given us a good many problems. Moreover one should be prepared for falsely low results, caused by platelets, cold-agglutinines, and for falsely high values, which result from the incomplete lysis of red blood cells.

Samples with high numbers of white blood cells give a falsely high hematocrit value; the MVC is therefore also too high, and the MCHC is too low.

As a conclusion we can say that the Hemalog is a reliable and precise instrument which can be used well in the routine hematological determination.

\section{Acknowledgments}

The assistance by Miss $A$. W. M. Hermus with the experiments is greatfully acknowledged.
5. Nicoll, W. D. \& Smith, A. A. (1971), Technicon Symposium London 393-401.

6. Dannesreiter, C. (1973), Technicon International Congress New York, HE 1-5.

7. Brittin, G., Dew, S. \& Fewell, E. (1971), Blood 38, 422-430.

8. Watkins, S. P. Jr. \& Shulman, N. R. (1970), Blood 36, 153158.
Drs. W. P. F. Rutten Stichting Medische Laboratoria Ignatiusstraat 11 Breda, The Netherlands 
